\title{
Sistem Informasi Pencatatan Data Warga Kelurahan Berbasis Mobile
}

\author{
Suryo Mulyawan Raharjo, Oky Dwi Nurhayati, Kurniawan Teguh Martono \\ Program Studi Sistem Komputer Fakultas Teknik Universitas Diponegoro \\ Jalan Prof. Sudharto, Tembalang, Semarang, Indonesia \\ suryomulyawanraharjo@gmail.com
}

\begin{abstract}
Abstrak-Pertumbuhan dan perkembangan teknologi informasi yang pesat mendukung manusia dalam membantu menyelesaikan berbagai masalah, khususnya pada pencatatan, penyimpanan, dan pengolahan data. Pencatatan, penyimpanan, dan pengolahan data secara konvensional yang menimbulkan banyak masalah seperti keakuratan, efektifitas dan efisiensi serta mobilitas, dapat diminimalkan dengan memanfaatkan teknologi informasi untuk membuat suatu sistem informasi.

Sistem informasi ini dibuat dengan menggunakan teknologi HTML5, JavaScript, dan CSS. Sistem informasi akan menggunakan database yang memiliki kelebihan dalam segi keamanan dan jumlah konektivitas yang dapat dilayani dalam satu waktu yaitu database MySQL. Proses pengembangan sistem informasi ini menggunakan tahapan System Development Life Cycle atau SDLC dan dengan metode Waterfall. Dengan teknik Waterfall proses pengembangan sistem informasi dapat menjadi lebih cepat dan berjalan baik.

Hasil akhir yang didapatkan dari proses pengembangan ini adalah terealisasinya suatu aplikasi berbasis mobile yang mempermudah pengguna dalam mencatat, menyimpan dan mengolah data warga yang memberikan informasi pertumbuhan warga pada suatu lokasi. Aplikasi ini meningkatkan keakuratan, efektifitas dan efisiensi serta tingkat mobiitas.
\end{abstract}

Kata kunci: Sistem Informasi, Aplikasi, Mobile, HTML5, JavaScript, MySQL

\section{PENDAHULUAN}

$\mathrm{T}$ EKNOLOGI informasi tumbuh dan berkembang dengan pesat pada masa kini. Dalam banyak hal teknologi informasi mendukung manusia untuk menyelesaikan berbagai masalah, salah satunya yaitu masalah dalam pencatatan dan pengolahan data.

Namun realitanya, pencatatan dan pengolahan data masih dilakukan secara manual. Sebagian besar manusia masih melakukan proses pencatatan dan pengolahan data secara konvensional yang memiliki berbagai hambatan dan masalah dalam keakuratan, efektifitas, dan efisiensi serta mobilitas. Salah satu contoh organisasi yang belum menerapkan teknologi dalam pencatatan dan pengolahan data adalah kelurahan. Organisasi kelurahan akan mengalami kesulitan dalam proses pencatatan dan pengolahan data yaitu semakin tidak akurat, lambat, dan sulit dalam akses data seiring dengan meningkatnya jumlah data yang masuk.

Pencatatan dan pengolahan data yang memanfaatkan teknologi informasi menjadi solusi utama untuk mengatasi berbagai hambatan dan masalah yang dihadapi dalam pencatatan dan pengolahan data secara konvensional. Dengan pencatatan dan pengolahan data yang memanfaatkan teknologi informasi, data akan tersimpan secara akurat dan teratur, yang kemudian nantinya data tersebut akan diolah dan ditampilkan dalam berbagai bentuk informasi yang akurat serta dengan biaya relatif kecil untuk membangunnya dan memiliki tingkat mobilitas yang tinggi.

Diharapkan setelah sistem diimplementasikan, akan membantu pekerjaan manusia dalam melakukan pencatatan dan pengolahan data. Sehingga pencatatan dan pengolahan data lebih efisien, akurat, serta mudah diakses.

\section{TINJAUAN PUSTAKA}

\section{A. Sistem Informasi Pencatatan Data}

Sistem informasi adalah suatu sistem buatan manusia yang secara umum terdiri atas sekumpulan komponen berbasis komputer dan manual yang dibuat untuk menghimpun, menyimpan, dan mengelola data serta menyediakan informasi keluaran kepada para pemakai. ${ }^{[1]}$

Sistem informasi pencatatan data merupakan sistem informasi yang mengumpulkan dan memproses data transaksi. Dalam tugas akhir sistem informasi pencatatan data dilakukan pada suatu kelurahan untuk mengetahui pertumbuhan penduduk.

\section{B. Pemrograman}

Bahasa pemrograman adalah bahasa yang dapat diterjemahkan menjadi kumpulan-kumpulan perintah dasar tersebut. Penerjemahan dilakukan oleh program komputer yang disebut dengan kompilator. Sintaks dari bahasa pemrograman lebih mudah dipahami oleh manusia daripada sintaks perintah dasar. Sedangkan komputer sendiri hanya dapat melaksanakan perintah dasar itu. Dengan demikian disinilah peran penting kompilator sebagai perantara antara bahasa pemrograman dengan perintah dasar. Kegiatan membuat program komputer dengan menggunakan bahasa pemrograman disebut pemrograman komputer. ${ }^{[2]}$

Hypertext Markup Language Version 5 (HTML5) adalah sebuah bahasa markup yang menstrukturkan isi dari World Wide Web (WWW), sebuah teknologi utama pada internet. Standar HTML5 menyempurnakan elemen-elemen lama yang terdapat pada standar sebelumnya, menambahkan elemenelemen yang lebih semantik dan menambahkan fitur-fitur baru untuk mendukung pembuatan aplikasi web yang lebih kompleks. ${ }^{[3]}$

JavaScript adalah kode-kode program kecil yang dapat digunakan untuk membuat halaman web terlihat lebih dinamis. Dengan menggunakan JavaScript kita dapat menambahkan beberapa fitur yang dapat membuat tampilan lebih menarik serta dapat juga membatasi aksi dari pengguna. Dengan JavaScript, navigasi menu yang lebih canggih serta efek grafis sederhana dapat dilakukan. ${ }^{[4]}$

Cascading Style Sheet (CSS) adalah template yang mengontrol pemformatan tag HTML pada sebuah halaman 
web. Konsep CSS mirip dengan template pada Microsoft Word. CSS dapat mengubah tampilan pada dokumen Microsoft Word dengan mengubah format pada style dokumen. Begitu juga CSS dapat mengubah tampilan halaman web dengan mengubah format pada tag HTML tertentu melalui CSS, untuk selanjutnya mengganti spesifikasi default dari penjelajah web untuk tag-tag tersebut. ${ }^{[5]}$

\section{Basis Data}

Basis data yang digunakan dalam tugas akhir ini bernama sikta, dengan jumlah tabel sebanyak 7, yaitu tabel provinsi, tabel kabupaten, tabel kecamatan, tabel kelurahan, tabel keluarga, tabel individu, dan tabel pengguna. Basis data dibentuk dengan menggunakan perangkat lunak sistem manajemen basis data SQL atau DBMS MySQL.

MySQL adalah perangkat lunak sistem manajemen basis data SQL atau DBMS yang multithread, multi-user, dengan sekitar 6 juta instalasi di seluruh dunia. MySQL tersedia sebagai perangkat lunak gratis dibawah lisensi GNU General Public License (GPL). ${ }^{[6]}$

\section{PERANCANGAN SISTEM}

Tahapan-tahapan dalam merancang sistem informasi pencatatan data warga kelurahan ini, yaitu terdiri atas Teknik dan Pemodelan Sistem / Informasi, Analisa Kebutuhan Perangkat Lunak, dan Desain.

\section{A. Teknik dan Pemodelan Sistem / Informasi}

Tahapan pertama dimana penulis mencari, mengumpulkan, dan mendefinisikan kebutuhan-kebutuhan dari pengguna sistem yaitu organisasi kelurahan secara keseluruhan. Tahapan ini menghasilkan rincian kebutuhankebutuhan organisasi kelurahan, untuk dapat diaplikasikan atau diterapkan ke dalam bentuk sistem.

Rincian kebutuhan-kebutuhan organisasi kelurahan yang didapatkan dari tahapan ini yaitu sebagai berikut :

1. Kebutuhan mencatat dan menyimpan data kartu keluarga.

2. Kebutuhan mencatat dan menyimpan data kartu tanda penduduk.

3. Kebutuhan mendinamiskan data kartu keluarga.

4. Kebutuhan mendinamiskan data kartu tanda penduduk.

5. Kebutuhan mengolah data kartu keluarga dan kartu tanda penduduk untuk menghasilkan suatu keluaran yaitu berupa laporan, total jumlah, dan grafik pertumbuhan data penduduk.

6. Kebutuhan pencarian data penduduk.

7. Kebutuhan peta wilayah kelurahan.

\section{B. Analisa Kebutuhan Perangkat Lunak}

Tahapan kedua dimana penulis mencari, mengumpulkan, dan mendefinisikan kebutuhan-kebutuhan sistem. Tahapan ini menghasilkan rincian domain informasi dari sistem, untuk menjadi dasar dalam membangun sistem.

1. Kebutuhan Antarmuka

Antarmuka dalam sistem merupakan bagian yang menghubungkan antara pengguna sistem dan sistem. Berdasarkan tahapan sebelumnya, maka dapat dihasilkan kebutuhan antarmuka sistem sebagai berikut :

Antarmuka sederhana, dalam membangun sistem harus memiliki antarmuka yang mudah dipahami pengguna sistem.

- Antarmuka konsisten, dalam membangun sistem harus memiliki antarmuka yang tetap dan tidak berubah-ubah, sehingga membuat pengguna sistem menjadi nyaman.
- Antarmuka mudah digunakan, dalam membangun sistem harus memiliki antarmuka yang tidak memerlukan waktu yang lama dan mudah untuk dipelajari pengguna sistem.

2. Kebutuhan Fungsi

Fungsi dalam sistem merupakan bagian yang melakukan tugas-tugas tertentu agar sistem tersebut berjalan. Berdasarkan tahapan sebelumnya, maka dapat dihasilkan kebutuhan fungsi sebagai berikut :

- Fungsi autentifikasi.

- Fungsi pengelola.

- Fungsi pemakai.

\section{Desain}

Tahapan ketiga dimana penulis merepresentasikan hasil yang didapatkan dari tahapan sebelumnya, berupa rincian kebutuhan-kebutuhan ke dalam bentuk cetak biru sistem. Tahapan ini menghasilkan cetak biru dari sistem, untuk menjadi acuan dalam membagun sistem.

- Entity Relationship Diagram (ERD)

ERD merupakan diagram yang menggambarkan struktur data dan hubungan antar data dalam suatu sistem. Berdasarkan tahapan sebelumnya, maka dapat dihasilkan ERD yang ditunjukkan pada Gambar 1 berikut.

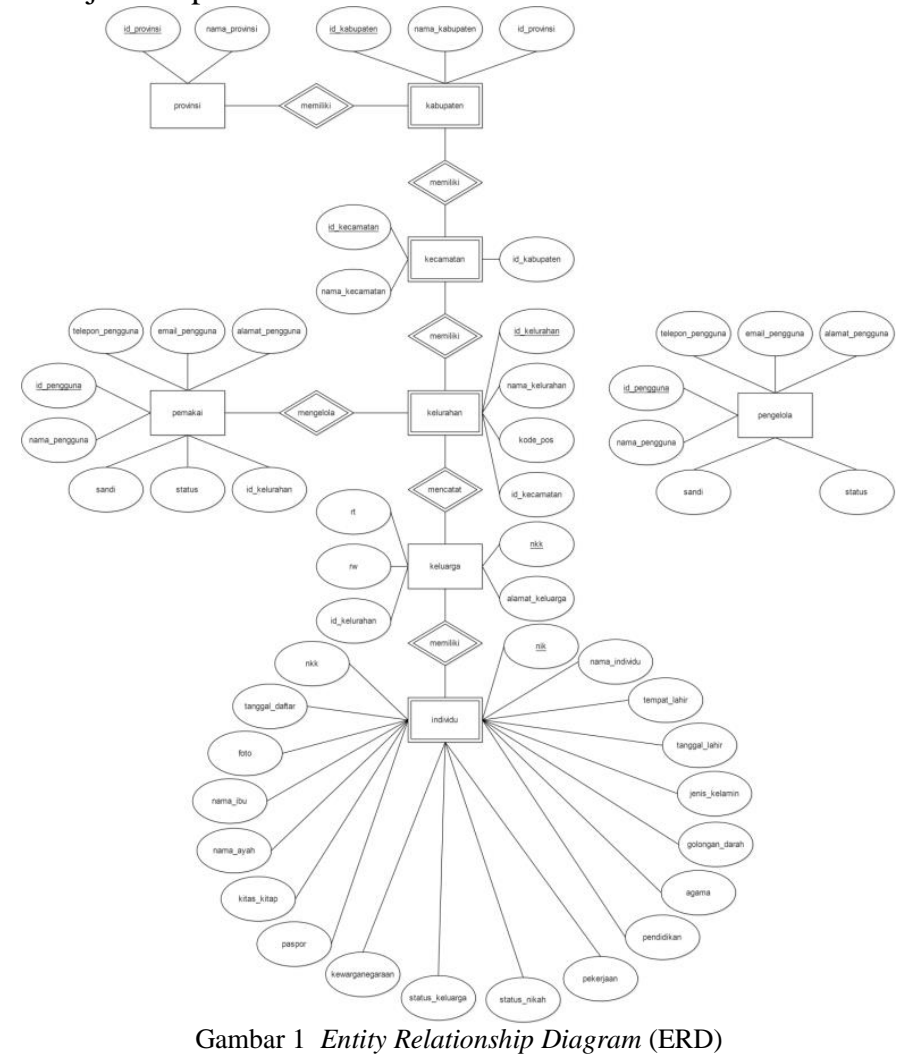

Data Flow Diagram (DFD)

DFD merupakan diagram yang menggambarkan aliran data antara proses-proses fungsional dalam suatu sistem. Berdasarkan tahapan sebelumnya dapat dihasilkan DFD yang ditunjukkan pada Gambar 2 berikut.

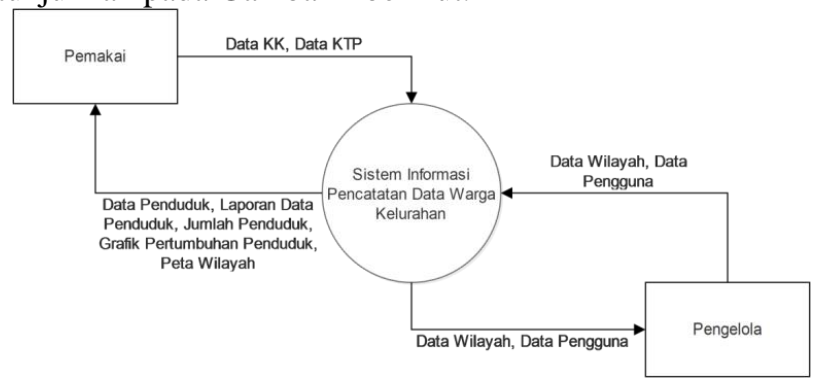

Gambar 2 Diagram Konteks 
Berdasarkan DFD level 0 / diagram konteks, dapat diuraikan DFD level 1 yang ditunjukkan pada Gambar 3 berikut.

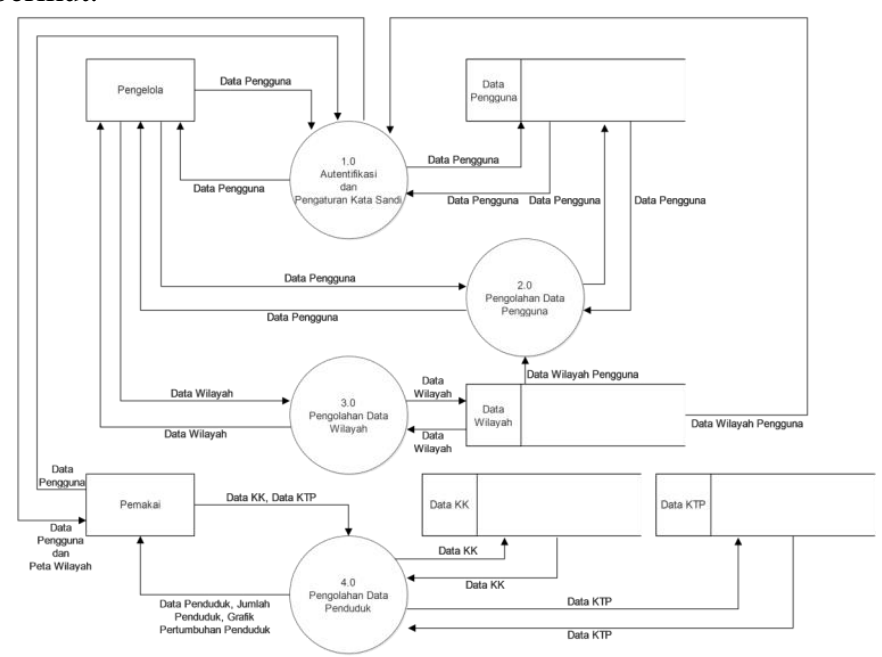

Gambar 3 Data Flow Diagram Level 1

\section{Diagram Alir}

Diagram alir merupakan diagram yang menggambarkan tahapan-tahapan dan urutan-urutan prosedur dari suatu sistem dalam menyelesaikan masalah. Berdasarkan tahapan sebelumnya dapat dihasilkan diagram alir sistem.

\section{- Antarmuka}

Antarmuka dalam sistem merupakan bagian yang menghubungkan antara pengguna sistem dan sistem. Berdasarkan tahapan sebelumnya dapat dihasilkan desain antarmuka.

\section{IMPLEMENTASI DAN PENGUJIAN SISTEM}

Tahapan-tahapan tingkat lanjut dalam merancang sistem informasi pencatatan data warga kelurahan ini, yaitu terdiri atas Pengkodean / Implementasi dan Pengujian.

\section{A. Pengkodean / Implementasi}

Tahapan keempat dimana penulis mempresentasikan hasil tahapan sebelumnya, berupa desain-desain ke dalam bentuk sistem yang nyata. Tahapan ini menghasilkan sistem yang nyata berdasarkan cetak biru sistem.

\section{Implementasi Basis Data}

Basis data merupakan bagian dari sistem yang menangani tugas untuk menyimpan data. Berdasarkan tahapan sebelumnya, maka dapat dihasilkan struktur basis data yang ditunjukkan pada Gambar 4 berikut.

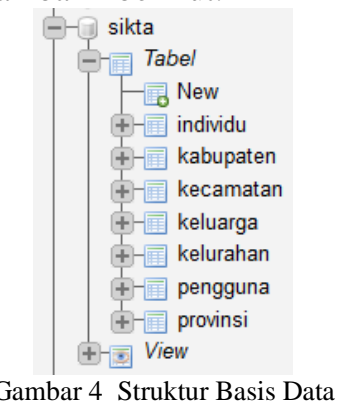

Setiap tabel dalam sistem informasi pencatatan data warga kelurahan memiliki hubungan antara satu dengan yang lainnya, ditunjukan pada Gambar 5 berikut.
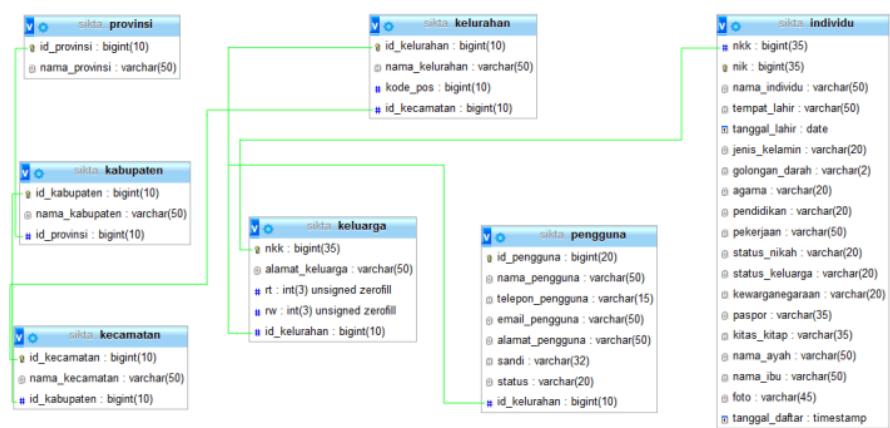

Gambar 5 Relasi Tabel

\section{Implementasi Program}

Program merupakan bagian dari sistem yang menangani tugas untuk melakukan fungsi sesuai kebutuhan. Berdasarkan tahapan sebelumnya, maka dapat dihasilkan program yang nyata.

\section{B. Pengujian}

Tahapan kelima dimana penulis melakukan uji coba terhadap hasil tahapan sebelumnya, berupa sistem nyata. Tahapan ini menghasilkan tabel hasil uji coba terhadap sistem nyata.

Metode pengujian sistem yang digunakan dalam menguji sistem informasi pencatatan data warga kelurahan adalah metode Kotak Hitam. Metode Kotak Hitam merupakan metode pengujian yang memperhatikan aspek fungsional dan tanpa perlu memperhatikan struktur internal dalam suatu sistem.

Pengujian pertama dengan melakukan pengujian pada menu pengelola ditunjukkan pada Tabel 1 berikut.

Tabel 1 Pengujian Menu Pengelola

\begin{tabular}{|l|l|l|l|}
\hline \multicolumn{1}{|c|}{$\begin{array}{c}\text { Nama } \\
\text { Pengujian }\end{array}$} & \multicolumn{1}{|c|}{$\begin{array}{c}\text { Bentuk } \\
\text { Pengujian }\end{array}$} & \multicolumn{1}{c|}{$\begin{array}{c}\text { Hasil yang } \\
\text { Diharapkan }\end{array}$} & $\begin{array}{c}\text { Hasil } \\
\text { Pengujian }\end{array}$ \\
\hline $\begin{array}{l}\text { Pengujian } \\
\text { Beranda }\end{array}$ & $\begin{array}{l}\text { Memberikan } \\
\text { event } \text { klik tombol } \\
\text { beranda }\end{array}$ & $\begin{array}{l}\text { Menampilkan } \\
\text { halaman } \\
\text { beranda }\end{array}$ & Berhasil \\
\hline $\begin{array}{l}\text { Pengujian } \\
\text { Pencarian } \\
\text { Data }\end{array}$ & $\begin{array}{l}\text { Memberikan } \\
\text { event } \text { klik tombol } \\
\text { pencarian data }\end{array}$ & $\begin{array}{l}\text { Menampilkan } \\
\text { halaman } \\
\text { pencarian data }\end{array}$ & Berhasil \\
\hline $\begin{array}{l}\text { Pengujian } \\
\text { Penambaha } \\
\text { n Data }\end{array}$ & $\begin{array}{l}\text { Memberikan } \\
\text { event } \text { klik tombol } \\
\text { penambahan data }\end{array}$ & $\begin{array}{l}\text { Menampilkan } \\
\text { halaman } \\
\text { penambahan } \\
\text { data }\end{array}$ & Berhasil \\
\hline $\begin{array}{l}\text { Pengujian } \\
\text { Manajemen } \\
\text { Data }\end{array}$ & $\begin{array}{l}\text { Memberikan } \\
\text { event } \text { klik tombol } \\
\text { manajemen data }\end{array}$ & $\begin{array}{l}\text { Menampilkan } \\
\text { halaman } \\
\text { manajemen data }\end{array}$ & Berhasil \\
\hline $\begin{array}{l}\text { Pengujian } \\
\text { Pengaturan }\end{array}$ & $\begin{array}{l}\text { Memberikan } \\
\text { event } \text { klik tombol } \\
\text { pengaturan }\end{array}$ & $\begin{array}{l}\text { Menampilkan } \\
\text { halaman } \\
\text { pengaturan }\end{array}$ & Berhasil \\
\hline
\end{tabular}

Pengujian kedua dengan melakukan pengujian pada menu pencarian data pengelola ditunjukkan pada Tabel 2 berikut. Tabel 2 Pengujian Menu Pencarian Data Pengelola

\begin{tabular}{|c|c|c|c|}
\hline $\begin{array}{c}\text { Nama } \\
\text { Pengujian }\end{array}$ & $\begin{array}{c}\text { Bentuk } \\
\text { Pengujian }\end{array}$ & $\begin{array}{c}\text { Hasil yang } \\
\text { Diharapkan }\end{array}$ & $\begin{array}{c}\text { Hasil } \\
\text { Pengujian }\end{array}$ \\
\hline $\begin{array}{l}\text { Pengujian } \\
\text { Pencarian } \\
\text { Data } \\
\text { Wilayah }\end{array}$ & $\begin{array}{l}\text { Memberikan } \\
\text { event klik tombol } \\
\text { pencarian data } \\
\text { wilayah dan } \\
\text { melakukan } \\
\text { pencarian data } \\
\text { wilayah }\end{array}$ & $\begin{array}{l}\text { Menampilkan } \\
\text { halaman } \\
\text { pencarian data } \\
\text { wilayah dan } \\
\text { menampilkan } \\
\text { data wilayah } \\
\text { berdasarkan kata } \\
\text { kunci yang } \\
\text { dimasukan }\end{array}$ & Berhasil \\
\hline $\begin{array}{l}\text { Pengujian } \\
\text { Pencarian } \\
\text { Data } \\
\text { Pemakai }\end{array}$ & $\begin{array}{l}\text { Memberikan } \\
\text { event klik tombol } \\
\text { pencarian data } \\
\text { pemakai dan } \\
\text { melakukan } \\
\text { pencarian data } \\
\text { pemakai }\end{array}$ & $\begin{array}{l}\text { Menampilkan } \\
\text { halaman } \\
\text { pencarian data } \\
\text { pemakai dan } \\
\text { menampilkan } \\
\text { data pemakai } \\
\text { berdasarkan kata } \\
\text { kunci yang }\end{array}$ & Berhasil \\
\hline
\end{tabular}




\begin{tabular}{|l|l|l|l|}
\hline & & dimasukan & \\
\hline & Memberikan & $\begin{array}{l}\text { Menampilkan } \\
\text { halaman }\end{array}$ & \\
Pengujian & event klik tombol & pencarian data & \\
pencarian data & pengelola dan & \\
Dencarian & pengelola dan & menampilkan & Berhasil \\
Pengelola & melakukan & datangelola & \\
& pencarian data & berdasarkan kata & \\
& kengelola & kunci yang & \\
& & dimasukan & \\
\hline
\end{tabular}

Pengujian ketiga dengan melakukan pengujian pada menu penambahan data pengelola ditunjukkan pada Tabel 3 berikut.

Tabel 3 Pengujian Menu Penambahan Data Pengelola

\begin{tabular}{|c|c|c|c|}
\hline $\begin{array}{c}\text { Nama } \\
\text { Pengujian }\end{array}$ & $\begin{array}{c}\text { Bentuk } \\
\text { Pengujian }\end{array}$ & $\begin{array}{c}\text { Hasil yang } \\
\text { Diharapkan }\end{array}$ & $\begin{array}{c}\text { Hasil } \\
\text { Pengujian }\end{array}$ \\
\hline $\begin{array}{l}\text { Pengujian } \\
\text { Penambaha } \\
\text { n Data } \\
\text { Provinsi }\end{array}$ & $\begin{array}{l}\text { Memberikan } \\
\text { event klik tombol } \\
\text { penambahan data } \\
\text { provinsi dan } \\
\text { melakukan } \\
\text { penambahan data } \\
\text { provinsi }\end{array}$ & $\begin{array}{l}\text { Menampilkan } \\
\text { halaman } \\
\text { penambahan } \\
\text { data provinsi } \\
\text { dan } \\
\text { menambahkan } \\
\text { data provinsi }\end{array}$ & Berhasil \\
\hline $\begin{array}{l}\text { Pengujian } \\
\text { Penambaha } \\
\text { n Data } \\
\text { Kabupaten }\end{array}$ & $\begin{array}{l}\text { Memberikan } \\
\text { event klik tombol } \\
\text { penambahan data } \\
\text { kabupaten dan } \\
\text { melakukan } \\
\text { penambahan data } \\
\text { kabupaten }\end{array}$ & $\begin{array}{l}\text { Menampilkan } \\
\text { halaman } \\
\text { penambahan } \\
\text { data kabupaten } \\
\text { dan } \\
\text { menambahkan } \\
\text { data kabupaten }\end{array}$ & Berhasil \\
\hline $\begin{array}{l}\text { Pengujian } \\
\text { Penambaha } \\
\text { n Data } \\
\text { Kecamatan }\end{array}$ & $\begin{array}{l}\text { Memberikan } \\
\text { event klik tombol } \\
\text { penambahan data } \\
\text { kecamatan dan } \\
\text { melakukan } \\
\text { penambahan data } \\
\text { kecamatan }\end{array}$ & $\begin{array}{l}\text { Menampilkan } \\
\text { halaman } \\
\text { penambahan } \\
\text { data kecamatan } \\
\text { dan } \\
\text { menambahkan } \\
\text { data kecamatan }\end{array}$ & Berhasil \\
\hline $\begin{array}{l}\text { Pengujian } \\
\text { Penambaha } \\
\text { n Data } \\
\text { Kelurahan }\end{array}$ & $\begin{array}{l}\text { Memberikan } \\
\text { event klik tombol } \\
\text { penambahan data } \\
\text { kelurahan dan } \\
\text { melakukan } \\
\text { penambahan data } \\
\text { kelurahan }\end{array}$ & $\begin{array}{l}\text { Menampilkan } \\
\text { halaman } \\
\text { penambahan } \\
\text { data kelurahan } \\
\text { dan } \\
\text { menambahkan } \\
\text { data kelurahan } \\
\end{array}$ & Berhasil \\
\hline $\begin{array}{l}\text { Pengujian } \\
\text { Penambaha } \\
\text { n Data } \\
\text { Pengguna }\end{array}$ & $\begin{array}{l}\text { Memberikan } \\
\text { event klik tombol } \\
\text { penambahan data } \\
\text { pengguna dan } \\
\text { melakukan } \\
\text { penambahan data } \\
\text { pengguna }\end{array}$ & $\begin{array}{l}\text { Menampilkan } \\
\text { halaman } \\
\text { penambahan } \\
\text { data pengguna } \\
\text { dan } \\
\text { menambahkan } \\
\text { data pengguna }\end{array}$ & Berhasil \\
\hline
\end{tabular}

Pengujian keempat dengan melakukan pengujian pada menu manajemen data pengelola ditunjukkan pada Tabel 4 berikut.

Tabel 4 Pengujian Menu Manajemen Data Pengelola

\begin{tabular}{|c|c|c|c|}
\hline $\begin{array}{c}\text { Nama } \\
\text { Pengujian }\end{array}$ & $\begin{array}{c}\text { Bentuk } \\
\text { Pengujian }\end{array}$ & $\begin{array}{c}\text { Hasil yang } \\
\text { Diharapkan }\end{array}$ & $\begin{array}{c}\text { Hasil } \\
\text { Pengujian }\end{array}$ \\
\hline $\begin{array}{l}\text { Pengujian } \\
\text { Manajemen } \\
\text { Data } \\
\text { Provinsi }\end{array}$ & $\begin{array}{l}\text { Memberikan } \\
\text { event klik tombol } \\
\text { manajemen data } \\
\text { provinsi dan } \\
\text { melakukan } \\
\text { pengubahan serta } \\
\text { penghapusan data } \\
\text { provinsi }\end{array}$ & $\begin{array}{l}\text { Menampilkan } \\
\text { halaman } \\
\text { manajemen data } \\
\text { provinsi dan } \\
\text { mengubah serta } \\
\text { menghapus data } \\
\text { provinsi }\end{array}$ & Berhasil \\
\hline $\begin{array}{l}\text { Pengujian } \\
\text { Manajemen } \\
\text { Data } \\
\text { Kabupaten }\end{array}$ & $\begin{array}{l}\text { Memberikan } \\
\text { event klik tombol } \\
\text { manajemen data } \\
\text { kabupaten dan } \\
\text { melakukan } \\
\text { pengubahan serta } \\
\text { penghapusan data } \\
\text { kabupaten }\end{array}$ & $\begin{array}{l}\text { Menampilkan } \\
\text { halaman } \\
\text { manajemen data } \\
\text { kabupaten dan } \\
\text { mengubah serta } \\
\text { menghapus data } \\
\text { kabupaten }\end{array}$ & Berhasil \\
\hline
\end{tabular}

\begin{tabular}{|c|c|c|c|}
\hline $\begin{array}{l}\text { Pengujian } \\
\text { Manajemen } \\
\text { Data } \\
\text { Kecamatan }\end{array}$ & $\begin{array}{l}\text { Memberikan } \\
\text { event klik tombol } \\
\text { manajemen data } \\
\text { kecamatan dan } \\
\text { melakukan } \\
\text { pengubahan serta } \\
\text { penghapusan data } \\
\text { kecamatan }\end{array}$ & $\begin{array}{l}\text { Menampilkan } \\
\text { halaman } \\
\text { manajemen data } \\
\text { kecamatan dan } \\
\text { mengubah serta } \\
\text { menghapus data } \\
\text { kecamatan }\end{array}$ & Berhasil \\
\hline $\begin{array}{l}\text { Pengujian } \\
\text { Manajemen } \\
\text { Data } \\
\text { Kelurahan }\end{array}$ & $\begin{array}{l}\text { Memberikan } \\
\text { event klik tombol } \\
\text { manajemen data } \\
\text { kelurahan dan } \\
\text { melakukan } \\
\text { pengubahan serta } \\
\text { penghapusan data } \\
\text { kelurahan }\end{array}$ & $\begin{array}{l}\text { Menampilkan } \\
\text { halaman } \\
\text { manajemen data } \\
\text { kelurahan dan } \\
\text { mengubah serta } \\
\text { menghapus data } \\
\text { kelurahan }\end{array}$ & Berhasil \\
\hline $\begin{array}{l}\text { Pengujian } \\
\text { Manajemen } \\
\text { Data } \\
\text { Pengelola }\end{array}$ & $\begin{array}{l}\text { Memberikan } \\
\text { event klik tombol } \\
\text { manajemen data } \\
\text { pengelola dan } \\
\text { melakukan } \\
\text { pengubahan serta } \\
\text { penghapusan data } \\
\text { pengelola }\end{array}$ & $\begin{array}{l}\text { Menampilkan } \\
\text { halaman } \\
\text { manajemen data } \\
\text { pengelola dan } \\
\text { mengubah serta } \\
\text { menghapus data } \\
\text { pengelola }\end{array}$ & Berhasil \\
\hline $\begin{array}{l}\text { Pengujian } \\
\text { Manajemen } \\
\text { Data } \\
\text { Pemakai }\end{array}$ & $\begin{array}{l}\text { Memberikan } \\
\text { event klik tombol } \\
\text { manajemen data } \\
\text { pemakai dan } \\
\text { melakukan } \\
\text { pengubahan serta } \\
\text { penghapusan data } \\
\text { pemakai }\end{array}$ & $\begin{array}{l}\text { Menampilkan } \\
\text { halaman } \\
\text { manajemen data } \\
\text { pemakai dan } \\
\text { mengubah serta } \\
\text { menghapus data } \\
\text { pemakai }\end{array}$ & Berhasil \\
\hline
\end{tabular}

Pengujian kelima dengan melakukan pengujian pada menu pengaturan pengelola ditunjukkan pada Tabel 5 berikut.

Tabel 5 Pengujian Menu Pengaturan Pengelola

\begin{tabular}{|c|l|l|l|}
\hline $\begin{array}{c}\text { Nama } \\
\text { Pengujian }\end{array}$ & \multicolumn{1}{|c|}{$\begin{array}{c}\text { Bentuk } \\
\text { Pengujian }\end{array}$} & \multicolumn{1}{|c|}{$\begin{array}{c}\text { Hasil yang } \\
\text { Diharapkan }\end{array}$} & $\begin{array}{c}\text { Hasil } \\
\text { Pengujian }\end{array}$ \\
\hline & $\begin{array}{l}\text { Memberikan } \\
\text { event } \text { klik tombol }\end{array}$ & $\begin{array}{l}\text { Menampilkan } \\
\text { halaman } \\
\text { pengaturan, }\end{array}$ & \\
Pengujian & pengaturan dan & $\begin{array}{l}\text { menampilkan } \\
\text { data akun yang } \\
\text { Pengaturan }\end{array}$ & Berhasil \\
& melakukan & dimiliki, dan & \\
& pengubahan kata & mengubah kata & \\
& sandi & sandi & \\
\hline
\end{tabular}

Pengujian keenam dengan melakukan pengujian pada menu pemakai ditunjukkan pada Tabel 6 berikut.

Tabel 6 Pengujian Menu Pemakai

\begin{tabular}{|l|l|l|l|}
\hline \multicolumn{1}{|c|}{$\begin{array}{c}\text { Nama } \\
\text { Pengujian }\end{array}$} & \multicolumn{1}{|c|}{$\begin{array}{c}\text { Bentuk } \\
\text { Pengujian }\end{array}$} & \multicolumn{1}{c|}{$\begin{array}{c}\text { Hasil yang } \\
\text { Diharapkan }\end{array}$} & $\begin{array}{c}\text { Hasil } \\
\text { Pengujian }\end{array}$ \\
\hline $\begin{array}{l}\text { Pengujian } \\
\text { Beranda }\end{array}$ & $\begin{array}{l}\text { Memberikan } \\
\text { event } \text { klik tombol } \\
\text { beranda }\end{array}$ & $\begin{array}{l}\text { Menampilkan } \\
\text { halaman } \\
\text { beranda }\end{array}$ & Berhasil \\
\hline $\begin{array}{l}\text { Pengujian } \\
\text { Pencarian } \\
\text { Data }\end{array}$ & $\begin{array}{l}\text { Memberikan } \\
\text { event } \text { klik tombol } \\
\text { pencarian data }\end{array}$ & $\begin{array}{l}\text { Menampilkan } \\
\text { halaman } \\
\text { pencarian data }\end{array}$ & Berhasil \\
\hline $\begin{array}{l}\text { Pengujian } \\
\text { Penambaha } \\
\text { n Data }\end{array}$ & $\begin{array}{l}\text { Memberikan } \\
\text { event } \text { klik tombol } \\
\text { penambahan data }\end{array}$ & $\begin{array}{l}\text { Menampilkan } \\
\text { halaman } \\
\text { penambahan } \\
\text { data }\end{array}$ & Berhasil \\
\hline $\begin{array}{l}\text { Pengujian } \\
\text { Manajemen } \\
\text { Data }\end{array}$ & $\begin{array}{l}\text { Memberikan } \\
\text { event } \text { klik tombol } \\
\text { manajemen data }\end{array}$ & $\begin{array}{l}\text { Menampilkan } \\
\text { halaman } \\
\text { manajemen data }\end{array}$ & Berhasil \\
\hline $\begin{array}{l}\text { Pengujian } \\
\text { Total Data }\end{array}$ & $\begin{array}{l}\text { Memberikan } \\
\text { event } \text { klik tombol } \\
\text { total data }\end{array}$ & $\begin{array}{l}\text { Menampilkan } \\
\text { halaman total } \\
\text { data }\end{array}$ & Berhasil \\
\hline $\begin{array}{l}\text { Pengujian } \\
\text { Grafik } \\
\text { Pertumbuh } \\
\text { an }\end{array}$ & $\begin{array}{l}\text { Memberikan } \\
\text { event } \text { klik tombol } \\
\text { grafik } \\
\text { pertumbuhan }\end{array}$ & $\begin{array}{l}\text { Menampilkan } \\
\text { halaman grafik } \\
\text { pertumbuhan }\end{array}$ & Berhasil \\
\hline $\begin{array}{l}\text { Pengujian } \\
\text { Peta }\end{array}$ & $\begin{array}{l}\text { Memberikan } \\
\text { event } \text { klik tombol }\end{array}$ & $\begin{array}{l}\text { Menampilkan } \\
\text { halaman peta }\end{array}$ & Berhasil \\
\hline
\end{tabular}




\begin{tabular}{|l|l|l|l|}
\hline Wilayah & peta wilayah & wilayah & \\
\hline $\begin{array}{l}\text { Pengujian } \\
\text { Pengaturan }\end{array}$ & $\begin{array}{l}\text { Memberikan } \\
\text { event } \text { klik tombol } \\
\text { pengaturan }\end{array}$ & $\begin{array}{l}\text { Menampilkan } \\
\text { halaman } \\
\text { pengaturan }\end{array}$ & Berhasil \\
\hline
\end{tabular}

Pengujian ketujuh dengan melakukan pengujian pada menu pencarian data pemakai ditunjukkan pada Tabel 7 berikut.

Tabel 7 Pengujian Menu Pencarian Data Pemakai

\begin{tabular}{|c|c|c|c|}
\hline $\begin{array}{c}\text { Nama } \\
\text { Pengujian }\end{array}$ & $\begin{array}{c}\text { Bentuk } \\
\text { Pengujian }\end{array}$ & $\begin{array}{c}\text { Hasil yang } \\
\text { Diharapkan }\end{array}$ & $\begin{array}{c}\text { Hasil } \\
\text { Pengujian }\end{array}$ \\
\hline $\begin{array}{l}\text { Pengujian } \\
\text { Pencarian } \\
\text { Data } \\
\text { Penduduk }\end{array}$ & $\begin{array}{l}\text { Memberikan } \\
\text { event } \text { klik tombol } \\
\text { pencarian data } \\
\text { penduduk dan } \\
\text { melakukan } \\
\text { pencarian data } \\
\text { penduduk } \\
\text { berdasarkan } \\
\text { nomor RW dan } \\
\text { RT, serta } \\
\text { memberikan } \\
\text { event klik pada } \\
\text { tombol unduh } \\
\text { laporan }\end{array}$ & $\begin{array}{l}\text { Menampilkan } \\
\text { halaman } \\
\text { pencarian data } \\
\text { penduduk dan } \\
\text { menampilkan } \\
\text { data penduduk } \\
\text { berdasarkan kata } \\
\text { kunci yang } \\
\text { dimasukan, serta } \\
\text { menghasilkan } \\
\text { laporan }\end{array}$ & Berhasil \\
\hline $\begin{array}{l}\text { Pengujian } \\
\text { Pencarian } \\
\text { Data Kartu } \\
\text { Keluarga }\end{array}$ & $\begin{array}{l}\text { Memberikan } \\
\text { event klik tombol } \\
\text { pencarian data } \\
\text { penduduk dan } \\
\text { melakukan } \\
\text { pencarian data } \\
\text { penduduk } \\
\text { berdasarkan nama } \\
\text { kepala keluarga } \\
\text { atau nkk, serta } \\
\text { memberikan } \\
\text { event klik pada } \\
\text { tombol unduh } \\
\text { laporan }\end{array}$ & $\begin{array}{l}\text { Menampilkan } \\
\text { halaman } \\
\text { pencarian data } \\
\text { kartu keluarga } \\
\text { dan } \\
\text { menampilkan } \\
\text { data penduduk } \\
\text { berdasarkan kata } \\
\text { kunci yang } \\
\text { dimasukan, serta } \\
\text { menghasilkan } \\
\text { laporan }\end{array}$ & Berhasil \\
\hline $\begin{array}{l}\text { Pengujian } \\
\text { Pencarian } \\
\text { Data Kartu } \\
\text { Tanda } \\
\text { Penduduk }\end{array}$ & $\begin{array}{l}\text { Memberikan } \\
\text { event klik tombol } \\
\text { pencarian data } \\
\text { penduduk dan } \\
\text { melakukan } \\
\text { pencarian data } \\
\text { penduduk } \\
\text { berdasarkan nama } \\
\text { penduduk atau } \\
\text { nik, serta } \\
\text { memberikan } \\
\text { event klik pada } \\
\text { tombol unduh } \\
\text { laporan }\end{array}$ & $\begin{array}{l}\text { Menampilkan } \\
\text { halaman } \\
\text { pencarian data } \\
\text { kartu tanda } \\
\text { penduduk dan } \\
\text { menampilkan } \\
\text { data penduduk } \\
\text { berdasarkan kata } \\
\text { kunci yang } \\
\text { dimasukan, serta } \\
\text { menghasilkan } \\
\text { laporan }\end{array}$ & Berhasil \\
\hline
\end{tabular}

Pengujian kedelapan dengan melakukan pengujian pada menu penambahan data pemakai ditunjukkan pada Tabel 8 berikut.

Tabel 8 Pengujian Penambahan Data Pemakai

\begin{tabular}{|c|c|c|c|}
\hline $\begin{array}{c}\text { Nama } \\
\text { Pengujian }\end{array}$ & $\begin{array}{c}\text { Bentuk } \\
\text { Pengujian }\end{array}$ & $\begin{array}{c}\text { Hasil yang } \\
\text { Diharapkan }\end{array}$ & $\begin{array}{c}\text { Hasil } \\
\text { Pengujian }\end{array}$ \\
\hline $\begin{array}{l}\text { Pengujian } \\
\text { Penduduk } \\
\text { Tidak } \\
\text { Memiliki } \\
\text { Kartu } \\
\text { Keluarga }\end{array}$ & $\begin{array}{l}\text { Memberikan } \\
\text { event klik tombol } \\
\text { penduduk tidak } \\
\text { memiliki kartu } \\
\text { keluarga dan } \\
\text { melakukan } \\
\text { penambahan data } \\
\text { penduduk }\end{array}$ & $\begin{array}{l}\text { Menampilkan } \\
\text { halaman } \\
\text { penduduk tidak } \\
\text { memiliki kartu } \\
\text { keluarga dan } \\
\text { menambahkan } \\
\text { data keluarga } \\
\text { dan penduduk }\end{array}$ & Berhasil \\
\hline $\begin{array}{l}\text { Pengujian } \\
\text { Penduduk } \\
\text { Memiliki } \\
\text { Kartu } \\
\text { Keluarga }\end{array}$ & $\begin{array}{l}\text { Memberikan } \\
\text { event klik tombol } \\
\text { penduduk } \\
\text { memiliki kartu } \\
\text { keluarga dan } \\
\text { melakukan }\end{array}$ & $\begin{array}{l}\text { Menampilkan } \\
\text { halaman } \\
\text { penduduk } \\
\text { memiliki kartu } \\
\text { keluarga dan } \\
\text { menambahkan }\end{array}$ & Berhasil \\
\hline
\end{tabular}

penambahan data data penduduk

penduduk

Pengujian kesembilan dengan melakukan pengujian pada menu manajemen data pemakai ditunjukkan pada Tabel 9 berikut.

Tabel 9 Pengujian Menu Manajemen Data Pemakai

\begin{tabular}{|c|c|c|c|}
\hline $\begin{array}{c}\text { Nama } \\
\text { Pengujian }\end{array}$ & $\begin{array}{c}\text { Bentuk } \\
\text { Pengujian }\end{array}$ & $\begin{array}{c}\text { Hasil yang } \\
\text { Diharapkan }\end{array}$ & $\begin{array}{c}\text { Hasil } \\
\text { Pengujian }\end{array}$ \\
\hline $\begin{array}{l}\text { Pengujian } \\
\text { Manajemen } \\
\text { Data Kartu } \\
\text { Keluarga }\end{array}$ & $\begin{array}{l}\text { Memberikan } \\
\text { event klik tombol } \\
\text { manajemen data } \\
\text { kartu keluarga } \\
\text { dan melakukan } \\
\text { pengubahan serta } \\
\text { penghapusan data } \\
\text { keluarga dan } \\
\text { kepala keluarga }\end{array}$ & $\begin{array}{l}\text { Menampilkan } \\
\text { halaman } \\
\text { manajemen data } \\
\text { kartu keluarga } \\
\text { dan mengubah } \\
\text { serta menghapus } \\
\text { data keluarga } \\
\text { dan kepala } \\
\text { keluarga }\end{array}$ & Berhasil \\
\hline $\begin{array}{l}\text { Pengujian } \\
\text { Manajemen } \\
\text { Data Kartu } \\
\text { Tanda } \\
\text { Penduduk }\end{array}$ & $\begin{array}{l}\text { Memberikan } \\
\text { event klik tombol } \\
\text { manajemen data } \\
\text { kabupaten dan } \\
\text { melakukan } \\
\text { pengubahan serta } \\
\text { penghapusan data } \\
\text { penduduk yang } \\
\text { bukan merupakan } \\
\text { kepala keluarga }\end{array}$ & $\begin{array}{l}\text { Menampilkan } \\
\text { halaman } \\
\text { manajemen data } \\
\text { kartu tanda } \\
\text { penduduk dan } \\
\text { mengubah serta } \\
\text { menghapus data } \\
\text { penduduk yang } \\
\text { bukan } \\
\text { merupakan } \\
\text { kepala keluarga }\end{array}$ & Berhasil \\
\hline
\end{tabular}

Pengujian kesepuluh dengan melakukan pengujian pada menu total data pemakai ditunjukkan pada Tabel 10 berikut. Tabel 10 Pengujian Total Data Pemakai

\begin{tabular}{|c|l|l|c|}
\hline $\begin{array}{c}\text { Nama } \\
\text { Pengujian }\end{array}$ & \multicolumn{1}{|c|}{$\begin{array}{c}\text { Bentuk } \\
\text { Pengujian }\end{array}$} & $\begin{array}{c}\text { Hasil yang } \\
\text { Diharapkan }\end{array}$ & $\begin{array}{c}\text { Hasil } \\
\text { Pengujian }\end{array}$ \\
\hline Penampilkan & \\
Pengujian & $\begin{array}{l}\text { Memberikan } \\
\text { event } \text { klik tombol } \\
\text { totaman total } \\
\text { tatal data }\end{array}$ & $\begin{array}{l}\text { data dan jumlah } \\
\text { penduduk } \\
\text { berdasarkan } \\
\text { waktu terkini }\end{array}$ & Berhasil \\
& & \\
\hline
\end{tabular}

Pengujian kesebelas dengan melakukan pengujian pada menu grafik pertumbuhan pemakai ditunjukkan pada Tabel 11 berikut.

Tabel 11 Pengujian Menu Grafik Pertumbuhan Pemakai

\begin{tabular}{|c|c|c|c|}
\hline $\begin{array}{c}\text { Nama } \\
\text { Pengujian }\end{array}$ & $\begin{array}{c}\text { Bentuk } \\
\text { Pengujian }\end{array}$ & $\begin{array}{c}\text { Hasil yang } \\
\text { Diharapkan }\end{array}$ & $\begin{array}{c}\text { Hasil } \\
\text { Pengujian }\end{array}$ \\
\hline $\begin{array}{l}\text { Pengujian } \\
\text { Grafik } \\
\text { Pertumbuh } \\
\text { an Tahunan }\end{array}$ & $\begin{array}{l}\text { Memberikan } \\
\text { event klik tombol } \\
\text { grafik } \\
\text { pertumbuhan } \\
\text { tahunan dan } \\
\text { melakukan } \\
\text { penelusuran } \\
\text { grafik balok dan } \\
\text { garis berdasarkan } \\
\text { range tahun } \\
\text { tertentu }\end{array}$ & $\begin{array}{l}\text { Menampilkan } \\
\text { halaman grafik } \\
\text { pertumbuhan } \\
\text { tahunan dan } \\
\text { grafik baik } \\
\text { balok maupun } \\
\text { garis sesuai } \\
\text { range tahun } \\
\text { yang dimasukan }\end{array}$ & Berhasil \\
\hline $\begin{array}{l}\text { Pengujian } \\
\text { Grafik } \\
\text { Pertumbuh } \\
\text { an Bulanan }\end{array}$ & $\begin{array}{l}\text { Memberikan } \\
\text { event klik tombol } \\
\text { grafik } \\
\text { pertumbuhan } \\
\text { bulanan dan } \\
\text { melakukan } \\
\text { penelusuran } \\
\text { grafik balok dan } \\
\text { garis berdasarkan } \\
\text { range tahun dan } \\
\text { bulan tertentu }\end{array}$ & $\begin{array}{l}\text { Menampilkan } \\
\text { halaman grafik } \\
\text { pertumbuhan } \\
\text { bulanan dan } \\
\text { grafik baik } \\
\text { balok maupun } \\
\text { garis sesuai } \\
\text { range tahun dan } \\
\text { bulan yang } \\
\text { dimasukan }\end{array}$ & Berhasil \\
\hline
\end{tabular}

Pengujian keduabelas dengan melakukan pengujian pada menu peta wilayah pemakai ditunjukkan pada Tabel 12 berikut. 
Tabel 12 Pengujian Peta Wilayah Pemakai

\begin{tabular}{|l|l|l|l|}
\hline \multicolumn{1}{|c|}{$\begin{array}{c}\text { Nama } \\
\text { Pengujian }\end{array}$} & \multicolumn{1}{|c|}{$\begin{array}{c}\text { Bentuk } \\
\text { Pengujian }\end{array}$} & \multicolumn{1}{|c|}{$\begin{array}{c}\text { Hasil yang } \\
\text { Diharapkan }\end{array}$} & $\begin{array}{c}\text { Hasil } \\
\text { Pengujian }\end{array}$ \\
\hline $\begin{array}{l}\text { Pengujian } \\
\text { Peta }\end{array}$ & Memberikan & $\begin{array}{l}\text { Menampilkan } \\
\text { halaman peta } \\
\text { Wilayah }\end{array}$ & event klik tombol \\
peta wilayah & $\begin{array}{l}\text { wilayah dan peta } \\
\text { wilayah daerah } \\
\text { kelurahan }\end{array}$ & Berhasil \\
\hline
\end{tabular}

Pengujian ketigabelas dengan melakukan pengujian pada menu pengaturan pemakai ditunjukkan pada Tabel 13 berikut. Tabel 13 Pengujian Pengaturan Pemakai

\begin{tabular}{|c|c|c|c|}
\hline $\begin{array}{c}\text { Nama } \\
\text { Pengujian }\end{array}$ & $\begin{array}{c}\text { Bentuk } \\
\text { Pengujian }\end{array}$ & $\begin{array}{c}\text { Hasil yang } \\
\text { Diharapkan }\end{array}$ & $\begin{array}{c}\text { Hasil } \\
\text { Pengujian }\end{array}$ \\
\hline $\begin{array}{l}\text { Pengujian } \\
\text { Pengaturan }\end{array}$ & $\begin{array}{l}\text { Memberikan } \\
\text { event klik tombol } \\
\text { pengaturan dan } \\
\text { melakukan } \\
\text { pengubahan kata } \\
\text { sandi }\end{array}$ & $\begin{array}{l}\text { Menampilkan } \\
\text { halaman } \\
\text { pengaturan, } \\
\text { menampilkan } \\
\text { data akun yang } \\
\text { dimiliki, dan } \\
\text { mengubah kata } \\
\text { sandi }\end{array}$ & Berhasil \\
\hline
\end{tabular}

\section{KESIMPULAN DAN SARAN}

\section{A. Kesimpulan}

Berdasarkan hasil perancangan sistem informasi pencatatan data warga kelurahan, maka dapat disimpulkan sebagai berikut :

1. Sistem informasi pencatatan data warga kelurahan dibangun dengan suatu teknologi yang sangat mendukung untuk pengintegrasian ke sistem lain dan pembangunan serta pengembangan sistem lama maupun baru dengan berbagai macam bahasa pemrograman.

2. Sistem informasi pencatatan data warga kelurahan dibangun dengan sangat memperhatikan keamanan data, sehingga data yang disimpan tidak dapat diakses oleh pihak yang tidak berwenang.

3. Sistem informasi pencatatan data warga kelurahan dibangun dengan sangat memperhatikan efisiensi data, sehingga data yang disimpan merupakan data yang berguna.

4. Sistem informasi pencatatan data warga kelurahan melakukan fungsi sesuai kebutuhan pengguna sistem.

\section{B. Saran}

Berdasarkan hasil pengujian sistem informasi pencatatan data warga kelurahan, maka dapat diberikan saran sebagai berikut :

1. Secara berskala melakukan pengecekan dan pembaharuan pada perangkat keras maupun lunak pada server untuk menjaga keamanan data.

2. Secara berskala melakukan backup data untuk memberikan pemecahan masalah jika terjadi kehilangan maupun kerusakan data pada media penyimpanan data server.

\section{DAFTAR PUSTAKA}

[1] N. Anggraeni, E. Retnadi and R. Kurniawati, "Perancangan Sistem Informasi Simpan Pinjam di KUD Mandiri Bayongbong," Algoritma, vol. IX, pp. 1-2, 2012.

[2] E. N. Wahyudi, "Algoritma dan Pemrograman Format Laporan dengan Pascal," Teknologi Informasi DINAMIK, vol. XII, pp. 26-27, 2007.

[3] M. Iqbal, M. Husni and H. Studiawan, "Implementasi Klien SIP Berbasis Web Menggunakan HTML5 dan Node.js," Teknik ITS, vol. I, p. 243, 2012.

[4] F. Constantianus and B. R. Suteja, "Analisa dan Desain Sistem Bimbingan Tugas Akhir Berbasis Web dengan Studi Kasus Fakultas Teknologi Informasi," Informatika UKM, vol. I, pp. 98-100, 2005.

[5] A. and Y. A. Efdom, "Perancangan dan Pembangunan Sistem Informasi Penjualan Online pada Toko Tinta," Sistem Informasi, vol. VIII, pp. 3-4, 2013.

[6] T. "Pengembangan Sistem Informasi Pengolahan Data Pendaftaran Pasien Rawat Jalan Menggunakan Basis Data MySQL (Studi Kasus pada Balai Besar Kesehatan Paru Masyarakat Surakarta)," INFOKES, vol. III, p. 28, 2013. 